Review

\title{
Advances in Precast Concrete Sandwich Panels toward Energy Efficient Structural Buildings
}

\author{
Sani Mohammed Bida 1,2, Farah Nora Aznieta Abdul Aziz 1,*, Mohd Saleh Jaafar 1, Farzad Hejazi \\ 1, Abu Bakar Nabilah ${ }^{1}$ \\ 1 Housing Research Centre (HRC), Department of Civil Engineering, Universiti Putra Malaysia (UPM), \\ 43400, Serdang, Selangor, Malaysia \\ 2 Department of Civil Engineering, Federal Polytechnic Bida, PMB 55, Bida, Niger State, Nigeria \\ 1 Affiliation 1,2; informsani@yahoo.com \\ 2 Affiliation 1; farah@upm.edu.com \\ 2 Affiliation 1; $\underline{\text { msj@upm.my }}$ \\ 2 Affiliation 1; farzad@fhejazi.com \\ 2 Affiliation 1; nabilah@upm.edu.my

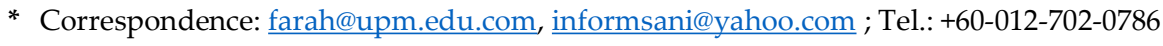

\begin{abstract}
Precast concrete sandwich panels (PCSP) are energy efficient building system that are achieved through an insulation layer created between the concrete wythes. The insulation layer is usually of low bearing strength material making it more applicable for non-structural building systems. Hence, shear connectors are introduced to improve its structural capacity, which subsequently degrade it thermal performance by serving as thermal bridges across the panel. This article review researches of alternative materials and methods used to improve the thermal efficiency as well as reduced the strength loss due to insulation in PCSP. The alternative materials are basalt fiber reinforced polymer (BFRP), carbon fiber reinforced polymer (CFRP), glass fiber reinforced polymer (GFRP), and foam concrete which are selected due to their low thermal conductivity for use in shear connection. While thermal path method has been used to prevent the effect of thermal bridges. Although, some of these materials have successfully achieved the desirable behaviours, however, several undesirable properties such as brittleness, bond slip, the sudden crushing of the panel system, and FRP failure below its ultimate strength were observed. Hence, the practicality of the alternative materials are still questionable despite its higher cost compared to the conventional steel and concrete used in PCSP system.
\end{abstract}

Keywords: alternative materials, fibre reinforced polymer, insulation, precast concrete sandwich panel, shear connection, thermal efficiency.

\section{Introduction}

Energy consumption in buildings is increasing due to human activities and global warming. The consumption is mostly as a result of thermal comfort due to electric heating and cooling requirements [1]. Investigation has shown that energy invested in thermal comfort for buildings in Mediterranean areas is about $47.8 \%$ of the total annual energy consumed in Spanish homes [2]. In Europe, about 30\% of total energy is used for thermal comfort. Also, electric heating and cooling requirement for housing account for about $50-70 \%$ of energy used in America [3]. On the average, buildings account for about $25-40 \%$ of total energy consumption which is mostly due to space heating or cooling requirements [4]. Energy performance assessment of existing residential housing recorded an average thermal transmittance (U-value) of $1.77 \mathrm{~W} / \mathrm{m} 2 \mathrm{~K}$ for wall panels [2]. The thermal transmittance recorded above fall short of the maximum recommended U-value for near Zero Energy Buildings (nZEB) [5]. This is 
coming at the expence of the scarce resources and low economic status coupled with environment consequences.

Therefore, various governments' agencies across the world have set targets in an effort to conserve the energy toward near zero energy buildings (ZEBs). This efforts are have made many countries to consider energy performance of building as a policy; in the Europe, EU Directive on Energy Performance of Buildings (EPBD) was set to the year 2020 in which all new buildings are expected to comply with "nearly zero energy buildings" [6]. In the United States, US Department of Energy (DOE) unveiled its strategic master plan toward "marketable zero energy homes in the year 2020 and commercial zero energy buildings in 2025" [7, 8]. Similar policies have been enacted in many countries as shown in Table 1.

Table 1. Green and sustainable building initiatives across the world

\begin{tabular}{|c|c|c|c|}
\hline Country & Green Building Program & $\begin{array}{l}\text { Year of } \\
\text { Initiation }\end{array}$ & Achievement to date \\
\hline Autralia & Green Star & 2003 & $\begin{array}{l}1900 \text { Green rated } \\
\text { projects }\end{array}$ \\
\hline Brazil & Aqua/ LEED Brasil & 2010 & $\begin{array}{l}1,308 \text { registered } \\
\text { projects }\end{array}$ \\
\hline Canada & $\begin{array}{l}\text { LEED canada/Green } \\
\text { Globes }\end{array}$ & 2000 & 2576 \\
\hline China & GBAS & 2006 & - \\
\hline Finland & PromisE & 1998 & - \\
\hline France & HQE & 1996 & 16000 \\
\hline Germany & DGNB & 2007 & 2800 certificates \\
\hline Hong Kong & HKBEAM & 2009 & Over 1000 \\
\hline India & $\begin{array}{l}\text { Indian Green Building } \\
\text { Council (IGBC) }\end{array}$ & 2007 & Over 4794 buildings \\
\hline Indonesia & $\begin{array}{l}\text { Indonesian Green } \\
\text { building Council } \\
\text { (Greenship) }\end{array}$ & 2009 & - \\
\hline Italy & Protocollo Itaca & 2000 & - \\
\hline Japan & CASBEE & 2004 & 500 Over buildings \\
\hline Korea & KGBC & 2000 & 1786 \\
\hline Malaysia & $\begin{array}{l}\text { Green Building Index } \\
\text { (GBI) }\end{array}$ & 2008 & Over 300 projects \\
\hline Mexico & LEED Mexico & 2000 & Over 94000 \\
\hline Netherlands & BREEAM Netherlands & - & - \\
\hline New Zealand & Green Star NZ & 2005 & 153 buildings \\
\hline Portugal & Lider A & 2005 & \\
\hline Singapore & Green Mark & 2005 & Over 360 projects \\
\hline South Africa & Green Star SA & 2007 & - \\
\hline United States & $\begin{array}{l}\text { Build it } \\
\text { Green/LEED/IGCC/ }\end{array}$ & 1993 & - \\
\hline United Kingdom & BREEAM & 1990 & - \\
\hline $\begin{array}{l}\text { United Arab } \\
\text { Emirate }\end{array}$ & Estidama & 2009 & - \\
\hline Jordan & EDAMA & 2009 & - \\
\hline Czech Republic & SBToolCZ & 2005 & - \\
\hline
\end{tabular}


Therefore, the most sustainable way to reduce energy consumption for indoor thermal comfort is by controlling the exterior-interior thermal mass transfers through the envelope of the building components. This can be achieved through energy retrofitting of existing buildings and an innovative energy efficient approach to new constructions [2]. According to Gervásio [9], energy sustainability in buildings is best achieved through material and energy efficiency. Hence, optimization of energy use such as in heating and cooling during building's service period is best achieved by introducing an insulation material into the building. This has called for a renewed interest in energy conservation and efficiency in building components such as precast concrete sandwich panels (PCSP) system which uses insulation as thermal barrier.

\section{Sandwich Systems}

Generally, sandwich refers to the combination of different material together either in layers or as a matrix to form a composite. This approach can be implemented in various materials and systems depending on its intended application. Before 1960, the greatest breakthrough of sandwich system is in aerospace applications specifically in the development of Mosquito aircraft during the World War II. Post-1960, tremendous alternative uses of sandwich technology were witnessed in many areas such as automobiles, refrigeration facilities, ship buildings and building construction [10-12]. As building material, sandwich panels are used as precast components named Precast Concrete Sandwich Panel (PCSP). It is a modification of solid panels produced using industrialized building system (IBS) approach and have gained popularity in civil engineering applications due to its thermal performance $[13,14]$. It offers better thermal efficiency than other traditional masonry construction or solid panel building methods due to the insulation material created between the concrete layers.

\subsection{Precast Concrete Sandwich Panels}

Precast concrete sandwich panels (PCSP) consist of two or more high strength layers refers to as wythes separated by a low strength material known as insulation. There are three major component parts of precast concrete sandwich panels, namely, the wythes, shear connectors and the insulation or void. The wythes are referred to as the concrete external rigid/solid body of considerable strength sufficient to resist an imposed load or self-weight of the structure. It is usually comprised of two or more concrete layers separated by a low strength material [15]. The thickness of the wythes depends on its intended application, shear embedment length required, concrete cover and stripping. Although, each manufacturer determines the appropriate thickness for their products [11]. According to Kim and Allard [16], the thickness of the concrete wythes ranges between 50 to $150 \mathrm{~mm}$. However, the minimum thickness of $38 \mathrm{~mm}$ has been observed in literature which was obtained from the summation of cover for both sides of wythes plus the thickness of reinforcement [17]. But, generally, the range of 40-150 $\mathrm{mm}$ has been accepted in practice which are connected using the shear connectors.

Shear connectors play a very importance role in determining the structural strength of the composite system. The material, shape, thickness, embedment length and spacing of shear connectors influence the behavior of panels significantly. The most commonly used shear connector material is steel. More recently, other materials such as fiber reinforced polymers (FRP) are studied in many investigations. Concrete studs are also used as a shear connection in reinforced concrete sandwich systems $[18,19]$.

Insulations are low strength materials with high thermal resistance used as a means of separating the concrete wythes in precast concrete sandwich panels. The thickness of the insulator depends on the thermal efficiency required by the manufacturers. PCI Handbook [11] recommended guidelines for estimation of thermal resistance of different materials. Sometimes, the space between wythes are design as vacuum insulated, hollow core or filled with insulator material; plastic, rubber, rigid foam, expanded polystyrene, extruded polystyrene, polyurethane, phenolic foam. Insulation materials 
differ in mechanical properties and their thermal resistance depends on the type of insulation used. The choice of type of insulation in PCSP system does not only depend on thermal insulation capacity, but also on the combined performance based on different properties such as thermal conductivity, water absorption, permeability, and thermal expansion [20]. Usually, low absorption insulation materials are used in other to minimize loss of water during production [17]. However, in many building applications, expanded polystyrene (EPS) is the most used insulator in PCSP. The reasons are due to its low cost, low water absorption, low density, and availability in open market.

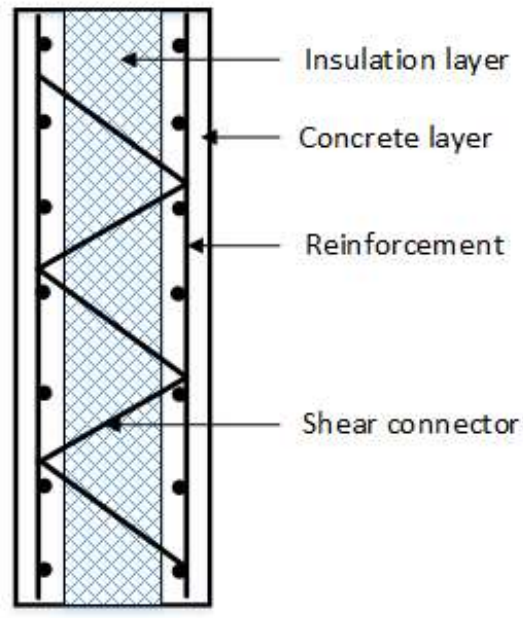

Figure 1: Section through precast concrete sandwich panel [21]

\section{Research advances in precast concrete sandwich panels}

Although, precast concrete sandwich panels (PSCP) offers better thermal efficiency than other solid wall building construction methods due to the insulation layer created between the concrete layers. However, the strength is sacrificed due to the inclusion of the insulation material to achieve a better thermal properties. Hence, the layers are connected by means of shear connectors through the insulation to improve the structural capacity and ensure composite action. Unfortunately, the connection that bind the individual layers together cause thermal bridges and are the main contributors to the thermal mass transfer from one side of the panel to the other [16, 22, 23]. Therefore, research advances in PCSP has taken two dimensions; the use of alternative materials for the fabrication of the panel components and design approach.

\subsection{Materials Approach}

A paradigm shift in the material used for the fabrication of the component parts of the PCSP system is witnessed from conventional concrete and steel to foamed concrete and fibre reinforced polymers (FRP) for wythes and shear connection, respectively in literature. Because, this materials are believed to exhibit lower thermal conductivity compared with the conventional materials.

\subsubsection{Alternative Material for Wythes in PCSP}

Material conductivity used in wythes production influences the rate of thermal transfer between its two sides. It has been generally established that thermal conductivity of material increases with increase in density. According to Hata [24], it has been proven that the highest density concretes 
produce the highest conductivity values. Therefore, many researchers have attempted to improve the thermal performance of concrete wythes by developing lightweight concrete known as foamed or aerated concrete in PCSP production. In 2015, Amran [25] defined foamed concrete as a light cellular concrete produced from mixture of foaming agent in mortar which contains randomly distributed air voids and have a density range of $400-1850 \mathrm{~kg} / \mathrm{m} 3$. It lower density makes it thermally more efficient than the conventional concrete. Also, foam concrete density of $1600 \mathrm{~kg} / \mathrm{m} 3$ exhibits thermal conductivity of about $0.66 \mathrm{~W} / \mathrm{mK}$ against $1.6 \mathrm{~W} / \mathrm{mK}$ recorded for conventional concrete of density $2200 \mathrm{~kg} / \mathrm{m} 3$ [26, 27]. Although, the low density of foamed concrete is also associated with low compressive strength which could impact negatively on the structural performance of PCSP.

Mohamad [10] reported that the compressive strength of the foamed concrete used in producing the panel wythes have a significant effect on the load capacity of the panel and premature crushing and buckling near the supports was observed when slenderness ratio above 18 was used. In addition, Mohamad and Muhammad [28] reported that premature material failure was observed when foamed concrete sandwich panel was tested under eccentric loading. It was inferred that the premature failure and local buckling was because of the lower compressive strength of the foamed concrete below $15 \mathrm{MPa}$. Also, full-scaled investigation of precast foamed concrete sandwich panel under axial loading with slenderness ratio between 14 to 20 indicated crushing behaviour both at the top and bottom of the panels $[29,30]$. This indicates that panels produced using foamed concrete exhibit sudden crushing, unless large cross-section are used. Also, bond slip has been reported between the foamed concrete and the reinforcement due to the low frictional resistance between the two materials.

In the other hand, Nooraini [27] reported that foamed concrete with a density range between $300 \mathrm{~kg} / \mathrm{m} 3$ to $1600 \mathrm{~kg} / \mathrm{m} 3$ exhibits thermal conductivity between $0.10 \mathrm{~W} / \mathrm{mK}$ to $0.66 \mathrm{~W} / \mathrm{mK}$. Also, Jones and McCarthy [31] revealed that the thermal conductivity of foam concrete ranges between 0.23 and $0.42 \mathrm{~W} / \mathrm{mK}$ at dry densities of 1000 and $1200 \mathrm{~kg} / \mathrm{m} 3$, respectively. The above mentioned conductivity values are far below conductivity of conventional concrete of $1.88 \mathrm{~W} / \mathrm{mK}$. Furthermore, Amran [25] reported that every $100 \mathrm{~kg} / \mathrm{m} 3$ reduction in density of foamed concrete lead to corresponding increase in thermal insulation by about $0.04 \mathrm{~W} / \mathrm{mK}$ of the total thermal insulation. However, the reduction in density becomes a disadvantage in terms of structural efficiency. It exhibits high porosity and water absorption behaviour coupled with low compressive strength. The above mentioned criterion are not suitable for load bearing external walls which are subjected to climatic conditions such as rain and snow load, making it highly susceptible to water absorption.

Ideally, PCSP should be made from material of low water absorption. Unfortunately, foamed concrete have high porosity and permeability which is described as a measure flow of water under pressure in a saturated porous medium [32]. It absorbs water twice as much as that of convention concrete at similar water cement ratio [33, 34]. Kearsley and Wainwright [34] reported that increase in cement ratio in foam concrete mixes increased the water vapour permeability proportionally most especially at the lower densities. Kochhar and Manohar [35] reported that moisture content is one of the major factors affecting the thermal conductivity of materials. The higher the material moisture content, the higher the thermal conductivity. Larson and Benner [36] also reported that thermal effectiveness of materials at a higher moisture content is reduced. Therefore, higher thermal conductivity values are recorded due to increased energy transfer by conduction and evaporationcondensation due to moisture transfer from warm to cold sides of the system. Moisture penetration into building materials could impact negatively on it thermal performance by increasing its thermal conductivity.

Therefore, it is essential to control moisture migration into the building components through careful material selection and design $[3,37]$. It is also on records that the thermal conductivity of water is about 25 times that of air. More so, Steiger and Hurd [38] reported that, when unit weight of concrete increased by $1 \%$ due to the water absorption, the thermal conductivity of the specimens increases $5 \%$, making porous materials like foamed concrete whose air voids are filled with water to exhibit higher values of thermal conductivity. This phenomenon of high water absorption of foamed concrete nullifies it advantages gain of perceived higher thermal performance against conventional concrete, coupled with the significant loss in structural strength of the foamed concrete when use as load bearing members. 
Therefore, wythes of a load bearing panels should be made from material of low water absorption without compromising its structural integrity. This feature could be achieved only if the strength of the panel is not affected or lowered. structural panel could be produced by increasing the thickness of the insulation layer while at the same time improve the shear connection design. By so doing, the strength loss due to insulation thickness could be augmented and the thermal performance improved.

\subsubsection{Alternative Material for Shear Connection in PCSP}

In order to reduce the effects of thermal mass transfer in PCSP, many research works have taken the option of using alternative materials that have low thermal conductivity such as carbon fibre reinforced polymer (CFRP) [39-41], Basalt fibre reinforced polymer (BFRP) [23, 42, 43], and Glass fibre reinforced polymer (GFRP) [44-51]. Theoretically, the structural behaviour and thermal performance of fibre reinforced polymers depends on their chemical composition.

According to Choi [46], it is difficult to predict the level of composite action, moment capacity and thermal deflections of FRP shear connector in PCSP, because of the variability in the chemical composition of the materials used in making the FRP. Besides, the material tends to exhibit many disadvantages particularly when used for structural applications. Naito [52] investigated the structural deformation behaviour of various configurations of FRP and steel shear ties in PCSP. It was observed that the FRP ties are stiffer than the steel ties. The latter produced a flexible response, coupled with large ductility. Furthermore, FRP materials are more expensive than the conventional steel material and the protrusion process during manufacturing of the FRP bars requires high-cost specialized machinery making it uneconomical for the proposed application [53]. Some other disadvantages such as bond-slip, brittleness, low failure strain, low modulus of elasticity, delamination under loading and brittle failure without clear warnings are also reported when FRP materials are used in PCSP system [45, 54-56].

In 2014, Tomlinson and Fam [50] investigated the effect of GFRP in the precast concrete sandwich panel by sand coating the GFRP material to reduce bond slip. No pull-out failure was observed due to the sand coating, however, all the GFRP connectors were observed to fracture during the tests. The fracture is the result of the brittleness of the GFRP material when compared with conventional steel that is a ductile material. Earlier, Woltman [49] reported that the shear strengths of GFRP shear connectors are significantly lower than the values specified by manufacturer when tested in panels. This is because the connectors are usually tested under tension rather than direct shear. When used in the panel system where it is subjected to direct shear, the GFRP connectors failed in strength far below it stated strength by the manufacturer.

Jiang [45] carried out a direct shear push-out test to assess the performance of Precast Concrete Sandwich Panel (PCSP) with W-shaped Glass Fibre-reinforced Polymer shear connectors. The results indicate an elastic-brittle response caused by the pull-out of the connectors before the ultimate strength was reached. This indicates that the SGFRP material did not exhibit ductility behaviour. Many investigations have been carried out on the structural performance of PCSP with the alternative materials as summarized in Table 2(a)-(c). Despite the numerous investigations in this regard available in literature, no corresponding report yet regarding the thermal performance of the PCSP assemblies [40,57]. Even though, report have shown that there is opposite behavior between the load capacity and thermal efficiency: increasing number of shear connectors increases the load capacity, but decreases thermal performance. However, Salmon [57] reported that the thermal conductivity of CFRP material is about $14 \%$ of steel conductivity, which encourages more research in using FRP as shear connector in PCSP system.

Table 2 (a), (b) and (c) shows the research trend in the area of precast concrete sandwich panel using the alternative materials for wythes and shear connection from 1994 to date. The table has been categorized according to the loading type, namely Axial, Flexural and Shear tests for Table 2(a), 2(b) and 2(c) respectively. The highest performance in terms of ultimate load is $1250 \mathrm{kN}$ which was recorded from the use of conventional concrete and steel for wythes and shear connection 
respectively as against the foamed concrete which recorded the ultimate load of $890 \mathrm{kN}$ coupled with higher early crack range of 63-94\%. In 1997, Salmon et al. introduced the use of FRP as shear connection material and since then, most attention have been drifted toward the use of the material for shear connection. Ultimate flexural load of $117.3 \mathrm{kN}$ was achieved by using conventional steel and concrete while the range of 4-95 kN has been recorded for FRP. Even though, the upper limit were obtained from the control samples that are made up of the conventional concrete and steel. Table 2(c) shows the shear behaviour of precast concrete sandwich panels. The range between 5-138 $\mathrm{kN} / \mathrm{m}$ was recorded mostly from the use of FRP for shear connection. The highest value of 138 was achieved due to the larger embedment length and the corrugation of the FRP shear connectors used in the specimen. The increase in the embedment length leads to increase in the cross sectional area of the sample, making it uneconomical for commercial application.

Table 2(a). Summary of previous works on PCSPs under Axial Loading

\begin{tabular}{|c|c|c|c|c|c|}
\hline Author & $\begin{array}{l}\text { Wythe } \\
\text { Material }\end{array}$ & $\begin{array}{l}\text { Shear } \\
\text { Connection } \\
\text { Material }\end{array}$ & $\begin{array}{l}\text { Insulation } \\
\text { Material }\end{array}$ & $\begin{array}{l}\text { Ultimate } \\
\text { Load } \\
(\mathbf{k N})\end{array}$ & $\begin{array}{l}\text { First } \\
\text { crack } \\
(\%)\end{array}$ \\
\hline Amran [29] & $\begin{array}{l}\text { Foamed } \\
\text { Concrete }\end{array}$ & steel & EPS & $250-850$ & $33-82$ \\
\hline $\begin{array}{l}\text { Rahman and Jaini } \\
\text { [58] }\end{array}$ & $\begin{array}{l}\text { Foamed } \\
\text { Concrete }\end{array}$ & steel truss & - & $280-441$ & - \\
\hline $\begin{array}{l}\text { Mohamad and } \\
\text { Hassan [59] }\end{array}$ & $\begin{array}{l}\text { Foamed } \\
\text { Concrete }\end{array}$ & steel & EPS & $355-890$ & $34-64$ \\
\hline Carbonari [60] & Concrete & steel & EPS & $102-666$ & - \\
\hline Gara [61] & Concrete & steel & EPS & $400-500$ & - \\
\hline Mohamad [10] & $\begin{array}{l}\text { Foamed } \\
\text { Concrete }\end{array}$ & steel & EPS & $250-600$ & $51-72$ \\
\hline $\begin{array}{l}\text { Mohamad and } \\
\text { Muhammad [28] }\end{array}$ & $\begin{array}{l}\text { Foamed } \\
\text { Concrete }\end{array}$ & steel truss & EPS & 188-355 & 63-94 \\
\hline Benayoune [17] & Concrete & steel & $\begin{array}{l}\text { polystyrene } \\
\text { foam }\end{array}$ & $\begin{array}{l}1250- \\
1450\end{array}$ & $44-79$ \\
\hline Benayoune [14] & Concrete & steel & EPS & 1051 & $38-55$ \\
\hline Farah [62] & Concrete & steel & EPS & $595-930$ & - \\
\hline
\end{tabular}

Table 2(b). Summary of previous works on PCSPs under Flexural Loading

\begin{tabular}{|c|c|c|c|c|c|}
\hline Author & $\begin{array}{l}\text { Wythe } \\
\text { Material }\end{array}$ & $\begin{array}{l}\text { Shear } \\
\text { Connection } \\
\text { Material }\end{array}$ & $\begin{array}{l}\text { Insulation } \\
\text { Material }\end{array}$ & $\begin{array}{l}\text { Ultimate } \\
\text { Load } \\
(\mathrm{kN})\end{array}$ & $\begin{array}{l}\text { First } \\
\text { crack } \\
(\%)\end{array}$ \\
\hline Amran [29] & $\begin{array}{l}\text { Foamed } \\
\text { Concrete }\end{array}$ & Steel & EPS & $31-40$ & $40-51$ \\
\hline Kang and Kim [63] & - & GFRP & $\begin{array}{l}\text { EPS, XPS and } \\
\text { VIP }\end{array}$ & - & - \\
\hline Kim and Choi [64] & Concrete & GFRP & XPS foam & $10-87$ & $30-78$ \\
\hline Kim and You [47] & Concrete & GFRP & $\begin{array}{l}\text { EPS, XPS } \\
\text { foam }\end{array}$ & $25-75$ & - \\
\hline
\end{tabular}




\begin{tabular}{llllll} 
Tomlinson and Fam [42] & Concrete & BFRP & EPS & $38-41$ & - \\
Tomlinson and Fam [50] & Concrete & $\begin{array}{l}\text { GFRP \& } \\
\text { concrete }\end{array}$ & Rigid foam & $17-95$ & $32-83$ \\
Sousa [65] & Concrete & GFRP & XPS & $60-70$ & - \\
Mathieson and Fam [66] & GFRP skin & GFRP & polyurethane & $7-28$ & - \\
& & & & & \\
Henin [67] & Concrete & GFRP & XPS & $44-90$ & - \\
Flores-Johnson and Li & Foamed & Steel & - & $18-44$ & - \\
[68] & Concrete, & encased & & & \\
Gara [61] & FRFC & concrete & & $13-20$ & \\
Frankl [69] & Concrete & Steel & EPS & $45-90$ & - \\
Pantelides [48] & Concrete & CFRP & XPS, EPS & $25-45$ & - \\
Lee and Pessiki [70] & Concrete & GFRP & EPS & $30-36$ & $20-52$ \\
Benayoune [71] & Concrete & Steel & - & 117.3 & $55-60$ \\
Lee and Pessiki [72] & Concrete & steel & polystyrene & & \\
Salmon [57] & Concrete & steel & - & - & - \\
Bush and Stine [73] & Concrete & FRP & - & $4.4-22$ & - \\
\hline
\end{tabular}

Table 2(c). Summary of previous works on PCSPs under Shear Loading

\begin{tabular}{llllll}
\hline Author & $\begin{array}{l}\text { Wythes } \\
\text { Material }\end{array}$ & $\begin{array}{l}\text { Shear } \\
\text { Connection } \\
\text { Material }\end{array}$ & $\begin{array}{l}\text { Insulation } \\
\text { Material }\end{array}$ & $\begin{array}{l}\text { Ultimate } \\
\text { Load } \\
\mathbf{( k N / m})\end{array}$ & $\begin{array}{l}\text { First } \\
\text { crack } \\
\mathbf{( \% )}\end{array}$ \\
\hline Tomlinson [23] & Concrete & BFRP & EPS & 42808 & - \\
Kazem [40] & Concrete & CFRP and GFRP & EPS, XPS & $30-105$ & - \\
foam & EPS, XPS & $49-138$ & - \\
Choi [46] & Concrete & GFRP & EPS & $25-90$ & - \\
Hodicky [39] & Concrete & CFRP & XPS & $21-78$ & - \\
Woltman [49] & Concrete & GFRP & EPS and XPS & $19-51$ & - \\
Oh [74] & Concrete & GFRP & XPS & $60-70$ & - \\
Sousa [65] & FRP & GFRP & EPS, XPS & $59-129$ & - \\
Soriano and Rizkalla & Concrete & GFRP and CFRP & & \\
[19] & & BFRP, CFRP, & EPS, XPS & $5-18$ & - \\
Naito [52] & - & GFRP \& solid & & & \\
& & concrete & & & - \\
\hline
\end{tabular}

EPS-expanded polystyrene, XPS-extruded polystyrene, CFRP- carbon fibre reinforced polymer

\subsubsection{Insulation Materials}

Manufacturers produce many types of thermal insulation materials with variable densities for use in buildings and other applications. Some of the commercially available insulation materials are: 
polystyrene, polyurethane board, blanket batt, rock wool, loose fill perlite, rigid form, reflective form, roll form, loose-fill form, foamed in place and glass fibre. The choice of insulation type depends on it intended application, thermal insulation capacity, water absorption behaviour and other thermal and physical properties required. The thermal conductivity of these materials are within the range of 0.026-0.05 (W/mK) depends on their densities. However, polystyrene offer better advantages of lower water absorption, high thermal insulation, and lightweight and above all does not release poisonous gases when ignited. Moreover, polystyrene products show least sensitivity to changes in temperature and are easy to handle (can be cut to size and adjusted) during installation [76]. This is more reason why more of polystyrenes are being used in precast concrete sandwich panels than other insulation materials.

Selection of appropriate insulation location in sandwich panels through optimization of location and thickness of the insulation material plays a vital role in reducing energy consumption by restraining heat transmission loads to and from the buildings and would consequently reduce the demand for air-conditioning or heating. Many research works have been carried out to investigate the appropriate location and thickness of the insulation materials for best performance. In 2006, Bolattürk [77] reported the minimum and maximum insulation thicknesses using polystyrene insulation material to be in the range 20 to $170 \mathrm{~mm}$ with about 22 to $79 \%$ energy savings. Ucar and Balo [78] investigated the optimum insulation thickness of wall system in four climate regions of Turkey, by using foamboard 1500, foamboard 3500 fiberglass and extruded polystyrene as insulation materials. However, it was recommended that the optimum insulation thickness between 10.6 to 76.4 $\mathrm{mm}$ should be used for best performance.

For a structural panels, the requirement for symmetry in the sizes of the two wythes is of paramount importance to sustain the load capacity and compositeness of the sandwich system. This can be ensured when the insulation is placed at the middle of the panel. This approach is consistent with the findings by Kossecka and Kosny [79] who reported that thermal performance of walls depend significantly on the type of climate, either hot or cold and it best performance is achieved by locating the insulating layer at the inner core of the walls. In 2011, Ozel [80] investigated thermal performance of extruded polystyrene (XPS) and expanded polystyrene (EPS) insulation materials based on optimum insulation thickness of building walls with different structure materials under dynamic thermal conditions. The result show that the optimum thickness of insulation material varies between 20 to $82 \mathrm{~mm}$. In 2012, Ekici [81] investigated the insulation thickness of expanded polystyrene, extruded polystyrene, Fiberglass, and foamed polyurethane materials in various wall assemblies. The result showed that an insulation thickness in the range of 20 and $186 \mathrm{~mm}$ is appropriate for best performance.

$\mathrm{Yu}$ [82] reported that selection and determination of appropriate insulation material and thickness is of paramount importance in reinforced concrete sandwich system and that expanded polystyrene proved to be the most efficient insulation material when compared with extruded polystyrene, foamed polyurethane, perlite and foamed polyvinyl chloride in terms of overall performance and cost and recommended between 53 to $236 \mathrm{~mm}$ as thickness of the insulation material. The thermal efficiency of a wall assembly system depends on the type of insulation, thickness, and density of the insulation material. Computing the total thermal resistance of a multilayered wall assembly would require summation of all the resistances of the individual layers [83]. The performance of the insulation resistance in the assembly system to heat flow would depend on how and where the insulation is installed. Location of insulation layer in a single layered wall panel is immaterial and when multi-layered insulation is used, the sum of the thickness of all the layers is the same as the optimum thickness in the single layered panel [84].

Tsilingiris [85] study the effect of the combined space distribution and thermal resistance on the transient thermal behaviour of a wall system. The insulation material was placed in different locations in the wall geometry. The insulation was observed to be more effective at the outer side and least in the inner room side of the wall. This claim was also supported by Kossecka and Kosny [86] that the best thermal performance could be achieved by location the insulation material at the exterior side of the wall assembly. Similar experiment by Ozel and Pihtili [87] showed that provision of 
insulation of equal thickness at outer and inner sides of the wall assembly yield the best performance in terms of thermal efficiency. This claim was also supported by Al-Sanea and Zedan [84].

Summarily, it could be deduce from the above reviews that the best insulation location is when the insulator is located at the middle or the exterior part of the panel assembly. However, the middle core provides a symmetrical behaviour for best composite action for structural applications. Also, the most effective thickness for insulation material in term of thermal resistance is 10.6-186 mm depending on the type of insulator. However, polystyrene have been recommended as the best when considering overall performance.

\subsection{Design Approach}

The main aim of designing precast concrete sandwich panel is to develop a thermally efficient panel. This aim could be achieved either through the use of alternative material or design method. The alternative materials approach as discussed above indicated promising prospect for used in PCSP. However, its application comes with many challenges such as bond slip, brittleness, low structural strength and uneconomical section. Therefore, innovative design approach could offer more economical and thermally efficient structural panels.

In 1987, Zarr [88] introduced a sandwich panel referred to as super-insulated wall panel by using thermal path approach. The panels were designed using timber material which are staggered in framing to increase thermal flow path and break direct thermal bridges between the two sides of the panels. The thermal insulation capacity of the super-insulated timber panels were observed to be three times that of the conventional wood panel. Similar concept was implemented in three-layer PCSP with a total thickness of $279.4 \mathrm{~mm}$ by Lee and Pessiki [89]. The panels indicated improved thermal performance by $19.8 \%$ compared with the control specimen of direct connection. However, the authors reported that the panel is un-economical due to its excessive thickness and required cumbersome production method leading to prolonged production time. Also, the excessive concrete volume leads to increase weight and cost of materials. In an attempt to improve the challenges aforementioned, the thermal path concept was adopted in a $150 \mathrm{~mm}$ thick two-layer super-insulated precast concrete structural sandwich panels (SIPCSSP) by Bida [90]. Three different staggered spacing of shear connectors were tested using hot box test method and verified by FEM model. Despite the conventional steel and concrete used in the panels, the results show improved thermal performance by $117 \%$ for $200 \mathrm{~mm}$ spacing, $207 \%$ for $300 \mathrm{~mm}$ spacing and $236 \%$ for $400 \mathrm{~mm}$ spacing as compared to the direct $200 \mathrm{~mm}$ shear connector spacing (control specimen). The results are well within the allowable near zero energy buildings (nZEB) requirements for new and sustainable buildings.

The thermal path approach implemented in PCSP using conventional materials is a design method that have demonstrated excellent thermal performance. At the same time, the challenges of brittleness, bond-slip and other related issues aforementioned in the use of alternative materials have been avoided. Therefore, more attention is needed to investigate structural performance of PCSP using the thermal path approach. The success of this approach could fast track compliance to the new trend of achieving the targets of near-Zero Energy Buildings enacted in many countries.

\section{Conclusions}

This paper presents a review of works carried out in the area of reinforced concrete sandwich panel system. It is observed that the research direction in this area has been concentrated on finding the most efficient panel system using alternative materials such as FRPs and foam concrete due to the high thermal conductivity of steel and conventional concrete. For a non-structural application, the existing system using alternative material is sufficient for use, since it requires only minimum shear connection. However, for structural application, better composite behaviour is required coupled with minimum thermal bridges.

In other to achieve composite behavior in a precast concrete sandwich panel system using the alternative materials, safety, economy, and durability in line with the basic principle of design should 
be given careful attention especially for structural applications. However, current alternative materials used in the PCSP system comes with many undesirable disadvantages for use in structural applications such as bond slip, brittleness, low shear strength and un-economical sections. The alternative materials in PCSP for use in structural applications are expected to exhibit ductile behavior as obtainable in steel to ensure sufficient avenue for warning and evacuation in the event of failure coupled with low thermal conductivity. These features are yet to be achieved from the alternative material such as BFRP, CFRP, GFRP and foamed concrete in reinforced concrete sandwich panels. Thus, more investigations are required in this regard using a conventional material such as steel reinforcement and concrete to develop more design methods like thermal path approach rather than alternative materials that seem unsustainable for practical application in load bearing systems. However, to achieved better and more efficient PCSP using FRP materials, a ductile and slip resistant materials are required to satisfy both the thermal and structural requirements.

Author Contributions: S.M.B and F.N.A. conceived the idea, wrote and analyzed the review; M.S.J, F.H and A.N updated and edited the paper. All authors have read and approved this review.

Funding: The authors would like to acknowledge the fund provider for making this research a reality by paying for all the materials, fabrication and experimental tests through research grant 06-01-04SF2364, Ministry of Science and Technology Malaysia (MOSTI).

Acknowledgments: The authors would like to acknowledge the contribution of the technicians and other individuals who contributed toward the success of this research.

Conflicts of Interest: The authors declare no conflicts of interest.

\section{References}

[1] Ryan, E.M.; Sanquist T.F. Validation of building energy modeling tools under idealized and realistic conditions. Energ Buildings. 2012, 47, 375-382.

[2] Domínguez, S.; Sendra J.; León A.; Esquivias P. Towards energy demand reduction in social housing buildings: Envelope system optimization strategies. Energies, 5 (7): 2263-2287. 2012.

[3] Al-Homoud, M.S. Performance characteristics and practical applications of common building thermal insulation materials. Building and environment. 2005, 40(3), 353-366.

[4] Robinson, A.; Lesage F.; Reilly A.; McGranaghan G.; Byrne G.; O’Hegarty R.; Kinnane O. A new transient method for determining thermal properties of wall sections. Energ Buildings. 2017, 142, 139146.

[5] EU nZEB. Report on Nearly zero-energy buildings. 2012 June 22, 2017]; Available from: https:/ec.europa.eu/energy/en/topics/energy-efficiency/buildings/nearly-zero-energy-buildings.

[6] Sartori, I.; Napolitano A.; Voss K. Net zero energy buildings: A consistent definition framework. Energ Buildings. 2012, 48, 220-232.

[7] Chua, S.C.; Oh T.H. Green progress and prospect in Malaysia. Renew Sust Energ Rev. 2011, 15(6), 2850-2861.

[8] Sood, S.M.; Chua K.; Peng D.L.Y. Sustainable development in the building sector: green building framework in Malaysia. ST-8: Best Practices \& SD in Construction. 2011, 1-8.

[9] Gervásio, H.; Santos P.; da Silva L.S.; Lopes A. Influence of thermal insulation on the energy balance for cold-formed buildings. Adv Steel Constr. 2010, 6(2), 742-766. 
[10] Mohamad, N.; Omar W.; Abdullah R. Precast Lightweight Foamed Concrete Sandwich Panel (PLFP) tested under axial load: preliminary results. Advanced Materials Research. Trans Tech Publ; 2011.

[11] PCI Handbook. PCI design handbook: precast and prestressed concrete. 2007, MNL-120. 6th ed. Chicago, IL: PCI.

[12] Davies, M. Wall transient heat flow using time-domain analysis. Building and Environment. 1997, 32(5), 427-446.

[13] Bai, F.; Davidson J.S. Analysis of partially composite foam insulated concrete sandwich structures. Eng Struct. 2015, 91, 197-209.

[14] Benayoune, A.; Samad A.A.A.; Trikha D.; Ali A.A.A.; Ashrabov A. Structural behaviour of eccentrically loaded precast sandwich panels. Constr Build Mater. 2006, 20(9), 713-724.

[15] Bida, S.M.; Aziz F.; Jaafar M.S.; Hejazi F.; Nabilah A.B. Efficient Structural Sandwich Wall Panels Devoid of Thermal Bridges, in Global Civil Engineering Conference (GCEC, 2017)Springer, 2017; pp. 59-67.

[16] Kim, Y.J.; Allard A. Thermal response of precast concrete sandwich walls with various steel connectors for architectural buildings in cold regions. Energ Buildings. 2014, 80, 137-148.

[17] Benayoune, A.; Samad A.A.; Ali A.A.; Trikha D. Response of pre-cast reinforced composite sandwich panels to axial loading. Constr Build Mater. 2007, 21(3), 677-685.

[18] Pessiki, S.; Mlynarczyk A. Experimental evaluation of the composite behavior of precast concrete sandwich wall panels. PCI J. 2003, 48(2), 54-71.

[19] Soriano, J.; Rizkalla S. Use of FRP grid for the composite action of concrete sandwich panels. Proceedings of the 11th International Symposium on Fiber Reinforced Polymer for Reinforced Concrete Structures (FRPRCS11), Guimarães, Portugal. 2013.

[20] Einea, A.; Salmon D.; Fogarasi G.; Culp T.; Tadros M. State of-the-art of precast sandwich panel system. PCI J. 1991, 36(6), 90-101.

[21] Hamed, E. Modeling, Analysis, and Behavior of Load-Carrying Precast Concrete Sandwich Panels. $J$ Struct Eng. 2016, 142(7), 04016036.

[22] Lee, B.-J.; Pessiki S. Thermal Behavior of Precast Prestressed Concrete Three-Wythe Sandwich Wall Panels, in Building Integration Solutions, 2006; pp. 1-15.

[23] Tomlinson, D.G.; Teixeira N.; Fam A. New shear connector design for insulated concrete sandwich panels using basalt fiber-reinforced polymer bars. J Compos Constr. 2016, 20(4), 04016003.

[24] Hata, R.M.; Hassan R.; Idayu H.; Arshad F. The thermal conductivity of selected tropical timber species using hot box method. Jurnal Teknologi. 2016, 78(5-4), 7-12.

[25] Amran, Y.M.; Farzadnia N.; Ali A.A. Properties and applications of foamed concrete; a review. Constr Build Mater. 2015, 101, 990-1005.

[26] Mohd Zahari, N.; Abdul Rahman I.; Zaidi A.; Mujahid A. Foamed concrete: potential application in thermal insulation. 2009.

[27] Nooraini, M.Z.; Ismail A.R.; Mujahid A.; Zahidi A. Foamed concrete: potential application in thermal insulation. 2010.

[28] Mohamad, N.; Muhammad H.M. Testing of precast lightweight foamed concrete sandwich panel with single and double symmetrical shear truss connectors under eccentric loading. Advanced Materials Research. Trans Tech Publ; 2011.

[29] Amran, Y.M.; Rashid R.S.; Hejazi F.; Safiee N.A.; Ali A.A. Structural behavior of laterally loaded precast foamed concrete sandwich panel. International Journal of Civil, Environmental, Structural, Construction and Architectural Engineering. 2016, 10(3). 
[30] Amran, Y.M.; Rashid R.S.; Hejazi F.; Ali A.A.; Safiee N.A.; Bida S.M. Structural Performance of Precast Foamed Concrete Sandwich Panel Subjected to Axial Load. KSCE J Civ Eng. 2018, 22(4), 1179-1192.

[31] Jones, M.; McCarthy A. Heat of hydration in foamed concrete: Effect of mix constituents and plastic density. Cement and concrete research. 2006, 36(6), 1032-1041.

[32] Sabir, B.; Wild S.; O'farrell M. A water sorptivity test for martar and concrete. Materials and Structures. 1998, 31(8), 568.

[33] Kearsley, E.P. The effect of high volumes of ungraded fly ash on the properties of foamed concrete. 1999, University of Leeds.

[34] Kearsley, E.; Wainwright P. Porosity and permeability of foamed concrete. Cement and concrete research. 2001, 31(5), 805-812.

[35] Kochhar, G.S.; Manohar K. Effect of moisture on thermal conductivity of fibers biological insulating materials. Thermal Performance of the Exterior Envelopes of Building VI. ASHRAE/DOE Conference. 1995.

[36] Larson, D.; Benner S. Field and laboratory studies of the thermal resistance of moist building insulation systems. Thermal Performance of the Exterior Envelopes of Building III, ASHRAE/DOE/BTECC Conference. 1985 .

[37] Straube, J.F. Moisture in buildings. ASHRAE journal. 2002, 44(1), 15.

[38] Steiger, R.; Hurd M. Lightweight insulating concrete for floors and roof decks. Concrete Construction. 1978, 23(7), 411-422.

[39] Hodicky, K.; Sopal G.; Rizkalla S.; Hulin T.; Stang H. Experimental and numerical investigation of the FRP shear mechanism for concrete sandwich panels. J Compos Constr. 2014, 19(5), 04014083.

[40] Kazem, H.; Bunn W.G.; Seliem H.M.; Rizkalla S.H.; Gleich H. Durability and long term behavior of FRP/foam shear transfer mechanism for concrete sandwich panels. Constr Build Mater. 2015, 98, 722 734.

[41] Mousa, M.A.; Uddin N. Experimental and analytical study of carbon fiber-reinforced polymer (FRP)/autoclaved aerated concrete (AAC) sandwich panels. Eng Struct. 2009, 31(10), 2337-2344.

[42] Tomlinson, D.; Fam A. Flexural behavior of precast concrete sandwich wall panels with basalt FRP and steel reinforcement. PCI J. 2015.

[43] Teixeira, N.; Tomlinson D.G.; Fam A. Precast concrete sandwich wall panels with bolted angle connections tested in flexure under simulated wind pressure and suction. PCI J. 2016.

[44] Huanzhi, J.; Zhengxing G.; Jiabin L. Composite behavior of sandwich panels with W-shaped SGFRP connectors. KSCE J Civ Eng. 2017, 1-11.

[45] Jiang, H.; Guo Z.; Liu J.; Liu H. The Shear Behavior of Precast Concrete Sandwich Panels with Wshaped SGFRP Shear Connectors. KSCE J Civ Eng. 2018, 1-11.

[46] Choi, K.-B.; Choi W.-C.; Feo L.; Jang S.-J.; Yun H.-D. In-plane shear behavior of insulated precast concrete sandwich panels reinforced with corrugated GFRP shear connectors. Compos Part B-Eng. 2015, 79, 419-429.

[47] Kim, J.; You Y.-C. Composite behavior of a novel insulated concrete sandwich wall panel reinforced with GFRP shear grids: Effects of insulation types. Materials. 2015, 8(3), 899-913.

[48] Pantelides, C.P.; Surapaneni R.; Reaveley L.D. Structural performance of hybrid GFRP/steel concrete sandwich panels. J Compos Constr. 2008, 12(5), 570-576.

[49] Woltman, G.; Tomlinson D.; Fam A. Investigation of various GFRP shear connectors for insulated precast concrete sandwich wall panels. J Compos Constr. 2013, 17(5), 711-721. 
[50] Tomlinson, D.; Fam A. Experimental investigation of precast concrete insulated sandwich panels with glass fiber-reinforced polymer shear connectors. ACI Struct J. 2014, 111(3), 595.

[51] Zhi, Q.; Guo Z. Experimental evaluation of precast concrete sandwich wall panels with steel-glass fiber-reinforced polymer shear connectors. Adv Struct Eng. 2017, 20(10), 1476-1492.

[52] Naito, C.; Hoemann J.; Beacraft M.; Bewick B. Performance and characterization of shear ties for use in insulated precast concrete sandwich wall panels. J Struct Eng. 2011, 138(1), 52-61.

[53] Lameiras, R.; Barros J.; Azenha M.; Valente I.B. Development of sandwich panels combining fibre reinforced concrete layers and fibre reinforced polymer connectors. Part II: Evaluation of mechanical behaviour. Compos Struct. 2013, 105, 460-470.

[54] Vilanova, I.; Baena M.; Torres L.; Barris C. Experimental study of bond-slip of GFRP bars in concrete under sustained loads. Compos Part B-Eng. 2015, 74, 42-52.

[55] Corradi, M.; Borri A.; Castori G.; Sisti R. Shear strengthening of wall panels through jacketing with cement mortar reinforced by GFRP grids. Compos Part B-Eng. 2014, 64, 33-42.

[56] Ascione, L.; Feo L. Modeling of composite/concrete interface of RC beams strengthened with composite laminates. Compos Part B-Eng. 2000, 31(6-7), 535-540.

[57] Salmon, D.C.; Einea A.; Tadros M.K.; Culp T.D. Full scale testing of precast concrete sandwich panels. ACI Struct J. 1997, 94, 239-247.

[58] Rahman, M.; Jaini Z. The combined finite-discrete element analysis of precast lightweight foamed concrete sandwich panel (PLFP) under axial load. Proceedings of the International Conference on Advances in Structural. 2013.

[59] Mohamad, N.; Hassan N. The structural performance of precast lightweight foam concrete sandwich panel with single and double shear truss connectors subjected to axial load. Advanced Materials Research. Trans Tech Publ; 2013.

[60] Carbonari, G.; Cavalaro S.; Cansario M.; Aguado A. Experimental and analytical study about the compressive behavior of eps sandwich panels. Materiales de Construcción. 2013, 63(311), 393-402.

[61] Gara, F.; Ragni L.; Roia D.; Dezi L. Experimental tests and numerical modelling of wall sandwich panels. Eng Struct. 2012, 37, 193-204.

[62] Farah, N.A.A.A. Structural Behaviour of Precast Concrete Sandwich Panels with Openings under Axial Load; MSc. Report; Universiti Putra Malaysia, 2002.

[63] Kang, W.-H.; Kim J. Reliability-based flexural design models for concrete sandwich wall panels with continuous GFRP shear connectors. Compos Part B-Eng. 2016, 89, 340-351.

[64] Kim, J.; Choi K.-S. Flexural strength for insulated concrete sandwich wall panel reinforced with glassfiber-reinforced polymer shear grids: roughness-induced mechanical bonding. Materials Research Innovations. 2015, 19(sup8), S8-397-S8-400.

[65] Sousa, C.F.; Barros J.A.; Azenha M.; Lameiras R.M. Flexural and shear behaviour of precast sandwich slabs comprising thin walled steel fibre reinforced self-compacting concrete. 7th RILEM International Conference on Self-Compacting Concrete and 1st RILEM International Conference on Rheology and Processing of Construction Materials. RILEM; 2013.

[66] Mathieson, H.; Fam A. Effect of internal ribs on fatigue performance of sandwich panels with GFRP skins and polyurethane foam core. Journal of Materials in Civil Engineering. 2013, 27(2), A4014005.

[67] Henin, E.; Morcous G.; Tadros M.K. Precast/prestressed concrete sandwich panels for thermally efficient floor/roof applications. Practice Periodical on Structural Design and Construction. 2013, 19(3), 04014013. 
[68] Flores-Johnson, E.; Li Q. Structural behaviour of composite sandwich panels with plain and fibrereinforced foamed concrete cores and corrugated steel faces. Compos Struct. 2012, 94(5), 1555-1563.

[69] Frankl, B.A.; Lucier G.W.; Hassan T.K.; Rizkalla S.H. Behavior of precast, prestressed concrete sandwich wall panels reinforced with CFRP shear grid. PCI J. 2011, 56(2), 42-54.

[70] Lee, B.-J.; Pessiki S. Experimental evaluation of precast, prestressed concrete, three-wythe sandwich wall panels. $P C I J$. 2008, 53(2).

[71] Benayoune, A.; Samad A.A.; Trikha D.; Ali A.A.; Ellinna S. Flexural behaviour of pre-cast concrete sandwich composite panel-experimental and theoretical investigations. Constr Build Mater. 2008, 22(4), 580-592.

[72] Lee, B.-J.; Pessiki S. Design and analysis of precast, prestressed concrete, three-wythe sandwich wall panels. PCI J. 2007, 52(4), 70-83.

[73] Bush, T.D.; Stine G.L. Flexural behavior of composite precast concrete sandwich panels with continuous truss connectors. PCI J. 1994, 39(2).

[74] Oh, T.S.; Jang S.J.; Lee K.M.; Yun H.D. Insulation type effect on the direct shear behavior of concrete sandwich panel (csp) with non-shear connectors. Advanced Materials Research. Trans Tech Publ; 2013.

[75] Cho, K.; Park S.Y.; Kim S.T.; Cho J.-R.; Kim B.-S. Shear connection system and performance evaluation of FRP-concrete composite deck. KSCE J Civ Eng. 2010, 14(6), 855-865.

[76] Abdou, A.A.; Budaiwi I.M. Comparison of thermal conductivity measurements of building insulation materials under various operating temperatures. Journal of Building Physics. 2005, 29(2), 171-184.

[77] Bolattürk, A. Determination of optimum insulation thickness for building walls with respect to various fuels and climate zones in Turkey. Applied thermal engineering. 2006, 26(11-12), 1301-1309.

[78] Ucar, A.; Balo F. Effect of fuel type on the optimum thickness of selected insulation materials for the four different climatic regions of Turkey. Appl Energ. 2009, 86(5), 730-736.

[79] Kossecka, E.; Kosny J. Hot-Box Testing of Building Envelope Assemblies-A Simplified Procedure for Estimation of Minimum Time of the Test. Journal of Testing and Evaluation. 2008, 36(3), 242249.

[80] Ozel, M. Thermal performance and optimum insulation thickness of building walls with different structure materials. Applied Thermal Engineering. 2011, 31(17-18), 3854-3863.

[81] Ekici, B.B.; Gulten A.A.; Aksoy U.T. A study on the optimum insulation thicknesses of various types of external walls with respect to different materials, fuels and climate zones in Turkey. Appl Energ. 2012, 92, 211-217.

[82] Yu, J.; Yang C.; Tian L.; Liao D. A study on optimum insulation thicknesses of external walls in hot summer and cold winter zone of China. Appl Energ. 2009, 86(11), 2520-2529.

[83] Peng, C.; Wu Z. In situ measuring and evaluating the thermal resistance of building construction. Energ Buildings. 2008, 40(11), 2076-2082.

[84] Al-Sanea, S.A.; Zedan M. Improving thermal performance of building walls by optimizing insulation layer distribution and thickness for same thermal mass. Appl Energ. 2011, 88(9), 3113-3124.

[85] Tsilingiris, P. Parametric space distribution effects of wall heat capacity and thermal resistance on the dynamic thermal behavior of walls and structures. Energ Buildings. 2006, 38(10), 1200-1211.

[86] Kossecka, E.; Kosny J. Influence of insulation configuration on heating and cooling loads in a continuously used building. Energ Buildings. 2002, 34(4), 321-331.

[87] Ozel, M.; Pihtili K. Optimum location and distribution of insulation layers on building walls with various orientations. building and environment. 2007, 42(8), 3051-3059. 
[88] Zarr, R.; Burch D.; Faison T.; Arnold C. Thermal Resistance Measurements of Well-Insulated and Superinsulated Residential Walls Using a Calibrated Hot Box. Journal of Thermal Insulation. 1987, 10(3), 197-218.

[89] Lee, B.-J.; Pessiki S. Analytical investigation of thermal performance of precast concrete three-wythe sandwich wall panels. PCI J. 2004, 49(4).

[90] Bida, S.M.; Aziz F.N.A.A.; Jaafar M.S.; Hejazi F.; Nabilah A.B. Thermal Performance of Superinsulated Precast Concrete Structural Sandwich Panels. Energ Buildings. 2018. 